\title{
Pengaruh UMKM terhadap Pertumbuhan Ekonomi di Sumatera Selatan
}

\author{
Lamazi \\ BPSDMD Prov. Sumatera Selatan \\ lamazibindu@gmail.com
}

\begin{abstract}
Abstrak
Penelitian ini bertujuan untuk melihat pengaruh UMKM terhadap pertumbuhan ekonomi di Sumatera Selatan. Hal ini dilatar belakangi dari permasalahan masih sedikitnya penduduk yang bekerja sebagai enterpreneur yaitu sebagai UMKM. Penelitian ini mengunakan data skunder dari BPS dari tahun 2015-2017. Teknik analisis yang digunakan adalah teknik analisis regresi linier ganda dengan metode OLS. Variabel UMKM dan tenaga kerja sebagai variabel bebas dan Pertumbuhan ekonomi sebagai Variabel terikat. Hasil penelitian menunjukan sebesar 93,57 persen variabel independen(UMKM dan tenaga kerja) menjelaskan pengaruh variabel terikat(pertumbuhan ekonomi). Sementara itu variabel Pertumbuhan ekonomi meningkat sebesar 31,03 persen setiap setiap peningkatan 1 persen UMKM.
\end{abstract}

Kata kunci: Wirausaha baru, PDRB, pekerja

\section{PENDAHULUAN}

UMKM sangat berperanan penting terhadap peningkatan kesejahteraan suatu negara khususnya negara berkembang termasuk Indonesia. Keberadaan UMKM sangat berpotensi akan meningkatkan kesempatan kerja serta peningkatan pendapatan. Bahkan Kontribusi sektor usaha mikro, kecil, dan menengah terhadap produk domestik bruto meningkat dari 57,84 persen menjadi 60,34 persen dalam lima tahun terakhir (www. Kemenprin.go.id).

Di Provinsi Sumatera Selatan, secara umum dalam lima tahun terakhir UMKM mengalami peningkatan. Pada tahun 2013 jumlah UMKM sebanyak 2002836 orang meningkat menjadi 2103268 orang pada tahun 2017(BPS Sumsel: 2018). Meskipun secara signifikan terjadi peningkatan, namun jika dilihat dari penduduk yang bekerja berdasarkan status pekerjaan utama yaitu yang bekerja dengan dibantuh oleh buruh tetap/buruh yang di upah masih sedikit. Hal ini dapat dilihat pada Gambar 1. di bawah ini: 
Gambar 1. Penduduk Berumur Tahun Keatas yang Bekerja Selama Seminggu yang Lalu Menurut Status Pekerjaan Utama dan Jenis Kelamin di Provinsi Sumatera Selatan, 2015-2017

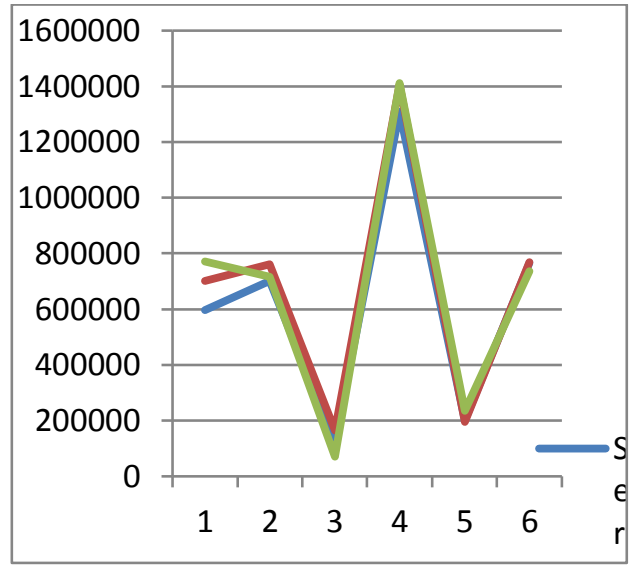

Ket:

1. = Berusaha sendiri

2. = berusaha dengan dibantu buruh tidak tetap

3. = berusaha dengan dibantu buruh tetap/buruh dibayar

4. = pegawai/buruh/karyawan

5. = pekerja bebas

6. = pekerja keluarga/tak dibayar

series $1=$ tahun 2015

series $2=$ tahun 2016

series $3=$ tahun 2017

Pada gambar 1meskipun terjadi trend peningkatan, namun secara umum penduduk yang bekerja berdasarkan status pekerjaan utamanya berusaha dengan dibantu buruh tetap/buruh yang dibayar tahun 2015 sampai 2017 adalah yang paling rendah yaitu dibawah 200000 orang. Bisa dibayangkan jika penambahannya pada pekerjaan utama bekerja dengan dibantu buruh tetap/buruhyang diupah di setiap tahunnya. Maka akan berdampak secara langsung terhadap penambahan tenaga kerja. Dan hal tersebut juga akan berdampak langsung terhadap pertumbuhan ekonomi.

Secara definisi berusaha dibantu oleh buruh tetap/buruh yang dibayar menurut BPS adalah seseorang dalam berusaha akan menanggung resiko sendiri atas pekerjaanya dan mempekerjakan paling sedikit satu orang tenaga kerja yang dibayar (BPS, 2018). Berdasarkan definisi ini maka yang bekerja di sektor utama ini diasumsikan adalah UMKM dan besar.

Berdasarkan hal tersebut, dalam peneliti ingin melihat seberapa besar pengaruh UMKM terhadap pertumbuhan PDRB. Pada penelitian ini dimasukan juga variabel tenaga kerja sebagai variabel kontrolnya. Penelitian ini bertujuan untuk seberapa besar pengaruh UMKM terhada PDRB di Sumatera Selatan. 


\section{METODE PENELITIAN}

Pelaksanaan penelitian ini dilakukan di Provinsi Sumatera Selatan. Penelitian ini megggunakan data sekunder yang berbentuk time series bersumber dari BPS Sumsel. Kecuali data untuk jumlah umkm berasal dari dua sumber yaitu untuk tahun 2010 sampai 2012 diambil dari BPS pusat. Sementara data jumlah UMKM dari tahun 2013 sampai 2017 diambil dari BPS Sumsel. Data berbentuk time series diambil dari tahun 2010 sampai 2017. Pada penelitian ini yang menjadi variabel bebas ada 2 yaitu, $\operatorname{UMKM}\left(\mathrm{X}_{1}\right)$ dan Tenaga $\operatorname{Kerja}\left(\mathrm{X}_{2}\right)$. Sementara variabel terikatnya (Y) yaitu pertumbuhan ekonomi yang diproxy dengan nilai PDRB. Populasi dalam penelitian ini sama dengan sampelnya yaitu jumlah seluruh UMKM di Sumatera Selatan. Sampel diambil mulai dari tahun 2010 sampai 2017.

\section{KAJIAN TEORI}

\subsection{Pengertian UMKM}

Menurut BPS, UMKM jika berdasarkan tenaga kerja yaitu usaha mikro merupakan entitas usaha yang memiliki tenaga kerja 1 sampai 5 orang dan usaha kecil memiliki tenaga kerja 5 sampai 19 orang sedangkan usaha menengah memiliki entitas tenaga kerja sebanyak 20 sampai 99 orang. Sementara jika dilihat dari sisi modal menurut Peraturan Menteri Keuangan No:316/PMK.016/1994 bahwa usaha kecil adalah perorangan atau badan usaha yang telah melakukan kegiatan/usaha yang mempunyai penjualan/ omset setinggi tingginya Rp 600.000.- dan asset/aktiva setinggi-tingginya Rp 600000 000,- (Tulus, 2009).

\subsection{Pengertian Tenaga Kerja}

Pengertian tenaga kerja berdasarkan pendapat Ignatia Rohana Sitanggang dan Nachrowi Djalal (Sari, 2013): (1) Tenaga kerja umumnya tersedia di pasar tenaga kerja, dan biasanya siap untuk digunakan dalam suatu proses produksi barang dan jasa. Kemudian perusahaan atau penerima tenaga kerja meminta tenaga kerja dari pasar tenaga kerja. Apabila tenaga kerja disebut bekerja, maka mereka akan mendapatkan jasa berupa upah/gaji. (2) Tenaga kerja yang terampil merupakan potensi sumber daya manusia yang sangat dibutuhkan dalam setiap perusahaan dalam mencapai tujuannya. Jumlah penduduk dan angkatan kerja yang besar, di satu sisi merupakan potensi sumber daya manusia yang dapat diandalkan, tetapi di sisi lain juga merupakan masalah besar yang berdampak pada berbagai sektor.

\subsection{Pengertian Produk Domestik Regional Bruto}

Pengertian PDRB adalahh merupakan nilai dari seluruh barang dan jasa yang diproduksi dalam jangka waktu tertentu biasanya dalam waktu satu tahun di suatu wilayah tertentu tanpa membedakan kepemilikann faktor faktor produksi yang digunakan dalam proses produksi tersebut. Pendapatan regional 
didefenisikan sebagai nilai produksi barang-barang dan jasa-jasa yang diciptakan dalam suatu perekonomian di dalam suatu wilayah selama satu tahun (Sukirno 2006).

\subsection{Penelitian Terdahulu}

Hapsah dkk (2014) hasil penelitinya menunjukan bahwa Pemberdayaan UKM berpengaruh secara signifikan terhadap pertumbuhan ekonomi daerah di Kota Batu. Namun, ketika diuji secara parsial hasil menunjukan bahwa hubungan variabel jumlah UKM dan tenaga kerja UKM tidak ditemukan pengaruh yang signifikan terhadap pertumbuhan ekonomi di Kota Batu. Nichlatul (2016) pada penelitianya menyebutkan terdapat pengaruh positif dan signifikan pengaruh perkembangan Usaha Kecil Menengah (UKM) terhadap pertumbuhan Produk Domestik Regional Bruto (PDRB). Kinasih (2014) pada penelitianya memperlihatkan hasiltemuanya menunjukkan bahwa variabel Pertumbuhan Jumlah Usaha dan Pertumbuhan Tenaga Kerja Industri UKM memberikan pengaruh positif dan signifikan terhadap Pertumbuhan PDRB.

\section{HASIL DAN PEMBAHASAN}

\subsection{Analisis Regresi Berganda}

Berdasarkan hasil olah data dengan menggunakan Program Excel diperoleh hasil sebagai berikut :

\section{Tabel.1. Hasil Pengolahan Data}

\begin{tabular}{|l|l|l|}
\hline Variabel & $\begin{array}{l}\text { Nilai Koefisien } \\
\text { regresi }\end{array}$ & signifikansi \\
\hline Konstann & -110 & 0,058 \\
\hline UMKM (X1) & 31,0266 & 0,012 \\
\hline $\begin{array}{l}\text { TenagaKerja } \\
(\mathrm{X} 2)\end{array}$ & 173,684 & 0,020 \\
\hline $\begin{array}{l}\mathrm{R}^{2}=0,9357 \\
\text { Sig F }=0,0001\end{array}$ \\
Sumber: Hasil Olah Data
\end{tabular}

Jika memperhatikan kembali bentuk persamaan yang digunakan dalam penelitian ini: $\mathrm{Y}=\alpha+\beta 1 \mathrm{X} 1+\beta 2 \mathrm{X} 2+$ ei. Sesuai tabel 1di atas, Persamaan model menjadi: $\mathrm{Y}=-3,9+31,02 \mathrm{X} 1+1,73,68+$ ei. Dari hasil regresi di atas menunjukan nilai signifikan $\mathrm{F}$ sebesar 0,001 . Hal ini menunjukan berarti penelitian ini sangat layak untuk diteliti. Jika dilihat dari nilai $\mathrm{R}^{2}$-nya bahwa terdapat pengaruh yang kuat bagi umkm di Sumatera Selatan terhadap peningkatan PDRB dengan memasukan variabel tenaga kerja sebagai variabel 
independen lainya. Hal ini dapat dilihat dari nilai R-Squre sebesar 0,93576, artinya variabel UMKM dan Variabel Tenagakerja mempengaruhi Variabel PDRB di Sumatera Selatan sangat tinggi yaitu sebesar 93,57 persen. sisanya yaitu sebesar 6,34 persen dipengaruhi oleh variabel lain yang tidak ada dalam penelitian ini.

Jika dilihat hubungan secara Parsial yaitu antara antara PDRB dengan UMKM pada penelitian ini menunjukan sebesar 31,03. Artiya jika terjadi peningkatan UMKM sebesar 1 persen, maka PDRB akan meningkat 31,03 persen dengan asumsi variabel tenaga kerja sebagai variabel lain dalam penelitian ini diabaikan. Dari hasil ini terllihat bahwa peran UMKM sangat besar pengaruhnya terhadap PDRB di Sumatera Selatan.

Sementara itu, untuk variabel tenaga kerja, secara parsial menunjukan sebesar 173,68. Hal ini bermakna jika terjadi peningkatan 1 persen saja tenaga kerja di Sumatera Selatan,akan meningkatkan PDRB di Sumatera Selatan sebesar 173,68 persen. Jika variabel UMKM sebagai variabel lain dalam penelitian ini diabaikan.

\section{Kesimpulan}

Kesimpulan dalam penelitian ini sebagai berikut:

1. UMKM berpengaruh signifikan dan positif terhadap pertumbuhan ekonomi

2. Tenaga Kerja berpengaruh signifikan dan positif terhadapanan pertumbuhan ekonomi

\section{Saran}

Dalam rangka peningkatan PDRB salah satu caranya menumbuhkan wirausaha baru sebagaimana yang diperoleh dari hasil penelitian ini. Beberap hal yang perlu dilakukan pemerintah antara lain:

a) Memberikan pelatihan kewirausahaan

b) Memberikan insentif baik berupa modal maupun paket start up dalam memulai usaha

\section{DAFTAR PUSTAKA}

Rahman, Siswat. 2016. Analisis Pengaruh Perkembangan Usaha Kecil dan Menengah Sektor Manufaktur Terhadap Pertumbuhan Ekonomi Di Kota Makasar.Ad'ministare Vol 3. 2019.

Konstribusi $U M K M$ Naik,

http://www.kemenperin.go.id/artikel/14200

Tambunan, Tulus T.H. 2009. UMKM di Indonesia, Ghalia Indonesia, Bogor 
Hidayati, Nurul. Pengaruh Pertumbuhan Usaha Mikro Kecil dan Menegah terhadap PDRB Kabupaten Bogor 2012-1015. repository.uinjkt.ac.id/dspace/bitstream/123456789/.../NURUL\%20HIDAYATI -FEB.pdf diunduh tanggal 26 juni 2019 pukul 04.18 wib.

Hapsah P, Hakim Abdul, dan Noor Irawan. 2014. Pengaruh Pertumbuhan Usaha Kecil Menengah (UKM) terhadap Pertumbuhan Ekonomi Daerah (Studi di Pemerintah Kota Batu). Wacana, Jurnal dan Humaniora. Volume 17 no.2. Universitas Brawijaya, Malang.

Nichlatu, Laily. 2016. ANALISIS PENGARUH PERKEMBANGAN USAHA KECIL MENENGAH (UKM) TERHADAP PERTUMBUHAN PRODUK DOMESTIK REGIONAL BRUTO (PDRB). Jurnal Pendidikan Ekonomi (jupe) Vol.4. No.3. UNESA

Sari, Nur Indah. 2013. Analisis Pengaruh Perkembangan Usaha Kecil Menengah Sektor Perdagangan Terhadap Pertumbuhan Ekonomi Di Kota Makassar. Tesis. Program Pasca Sarjana Universitas Negeri Makassar

2006. Makro Ekonomi Teori Pengantar. PT. Raja Grafindo Persada, Jakarta.

Kinasih, Sekar Ajeng(2011) Pengaruh Perkembangan UKM Terhadap Pertumbuhan PDRB Kabupaten Bantul. 1994 - 2009. S1 thesis, UAJY.Yogyakarta. 